\title{
Changes in Lipid Composition in the Flavedo Tissue of Naruto (Citrus medioglobosa) during Fruit Development
}

\author{
Bing-Shan FuH \\ Division of Science of Biological Resources, \\ The Graduate School of Science and Technology \\ Takao Ichil, Tetsu Nakanishi and Yoshitaka KawaI \\ Faculty of Agriculture, Kobe University, Kobe 657
}

\begin{abstract}
Summary
Seasonal changes in lipid composition in the flavedo tissues of Naruto fruit were determined during August to early June.

Total fatty acid content of phospho- and glycolipids, particularly that of glycolipids, decreased considerably with increased aging of the rind except during midwinter. In mid-winter that of neutral, phospho- and glycolipids showed a sharp peak, due largely to an increase in linoleic $(18: 2)$ acid in the first two and linolenic $(18: 3)$ acid in the last.

Content of major phospholipids, phosphatidylcholine (PC) and phosphatidylethanolamine (PE) ; and content of major glycolipids, mono-(MGDG) and di-galactosyldiglyceride (DGDG), behaved in a way similar to that of phospho- and glycolipid total fatty acids, respectively. Seasonal variations in DGDG content were paralleled by, but greater than MGDG content. The PC/PE ratio decreased steadily from August to December and thereafter remained unchanged. Free sterol content decreased from August to October and thereafter changed little except for showing a peak in mid-winter. However, the sterol/phospholipid ratio was relatively constant during winter. The sitosterol/stigmasterol ratio more than doubled in the maturing period (December-June) compared with that in the growing period (August-October).
\end{abstract}

\section{Introduction}

In temperate zones, citrus fruits grow in hot summer and enter the maturation period in fall when air temperature is lowered. The middle- and late-season fruits mature during winter-spring. Thus they must adapt to a wider range of temperature difference. During the maturation period the rind softens, and this makes the fruit susceptible to various physiological disorders(3). 'Rind yellow spot' of Naruto (Citrus medioglobosa Hort. ex Tanaka) is such a disorder which appears in the maturing fruit during winter (12).

Received for publication June 1, 1987.
It is well known that the plant can adapt to changes in the ambient temperature by adjusting its biological membrane fluidity (26). Membrane fluidity also changes according to aging and senescence of plant tis$\operatorname{sues}(2,4,16)$. There is considerable evidence that membrane fluidity is regulated by changes in the unsaturated fatty acid composition $(17,30)$ and/or the sterol/phospholipid ratio $(2,4,16,30)$. However, little is known about changes in the lipid composition in the rind tissues of citrus fruits during development. The objective of the present experiment was to clarify changes in lipid composition in the flavedo tissues of Naruto fruit in relation to changes in ambient temperature and aging of the rind. 


\section{Materials and Methods}

Plant material Naruto fruits were obtained from the two trees in an orchard at Tsuna, Awaji island. A sample of 10 fruits was picked from each of the two trees periodically between middle August and early June in 1985-1986. One day after harvest, rinds were removed from the fruits and trimmed of albedo tissues with a razor blade. The remaining flavedo tissues were used for the lipid extraction, and the results were presented as mean values of the two trees.

Lipid extraction Total lipids were extracted and purified according to O'Neill et al. (24) except that chloroform : methanol was used for reextraction instead of chloroform : isopropanol(5). The purified lipid extracts were dissolved in chloroform and stored in the dark at $-20^{\circ} \mathrm{C}$ under nitrogen.

Lipid separation and analysis The purified lipid extract was separated into neutral, glyco- and phospholipid fractions by silica gel chromatography(20). The phospho- and glycolipid fractions were further separated by one-dimentional thin layer chromatography (TLC) on silica gel $\mathrm{G}$ with chloroform : methanol : $7 \mathrm{M} \mathrm{NH} \mathrm{NH}_{4} \mathrm{OH}(65: 30: 4, \mathrm{v} / \mathrm{v} / \mathrm{v}$ ) and with chloroform: methanol: acetic acid: water $(85: 15: 10: 3, \mathrm{v} / \mathrm{v} / \mathrm{v})$, respectively. The seprarated individual lipids were visualized with iodine vapor and tested against samples of known lipids. The concentration of phospholipids was determined as $\mathrm{Pi}$ by the method of Bartlett(1), following digestion by $72 \%$ perchloric acid. That of glycolipids was determined as galactose by the phenol-sulfuric acid method(27). Free sterols, prepared from the neutral lipid fractions, were purified according to the method of Pauls and Thompson(25) except that the dried neutral fractions were dissolved in $2 \mathrm{ml}$ of boiling ethanol instead of $4 \mathrm{ml}$ of acetone : ethanol $(1: 1, \mathrm{v} / \mathrm{v})$, and that the sterols were precipitated with $2 \mathrm{ml}$ of hot $0.5 \%$ digitonin and $0.6 \mathrm{ml}$ of hot water. The purified free sterols were analyzed by a Shimazu gas chromatograph (GC) equipped with flame ionizing detector. The chromatograph was operated under the following conditions : at $260^{\circ} \mathrm{C}$ isothermal; $2 \mathrm{~m}$ by $3 \mathrm{~mm}$ column with $2 \%$ OV-17 on Chromosorb W, 80-100 mesh (Gasukuro Kogyo Co.). Cholestane was used as the internal standard.

Fatty acid analysis Fatty acids were methylated by a slight modification of the method of Metcalfe and Schmitz(18), and analyzed by $\mathrm{GC}(5)$. Double bound index (DBI) was calculated from the sum of the products of the relative amounts of each fatty acid and its number of double bonds.

\section{Results}

Fruit growth Fig. 1 shows changes in fresh weight of the fruit and mean air temperature during the period from August 1985 until following June. Fruit fresh weight increased from August to early December after which no significant increase was observed. On the other hand, rind color began to change through late October into early November as the air temperature decreased, and the typical orange color developed in February. Thereafter, the fruit tended to gradually regreen with an increase in air temperature.

Fatty acids The major fatty acids in the flavedo tissues of the fruit were palmitic $(16: 0)$, stearic $(18: 0)$, oleic $(18: 1), 18: 2$ and $18: 3$ acids. The proportion of $18: 0$ was lowest. Fig. 2 shows seasonal changes in fatty acid content on a fresh weight basis. The neutral lipid total fatty acid content, particularly $18: 3$ content, increased markedly (nearly four times) from August until

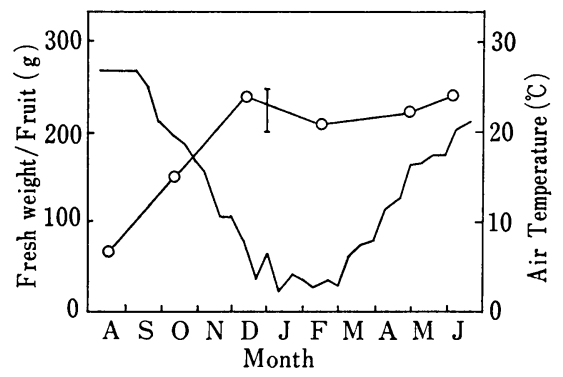

Fig. 1. Fruit growth and mean air temperature during the period from August, 1985 to June, 1986. Vertical bar indicates L. S. D. (5\%)

$\bigcirc-\bigcirc:$ Fresh weight, $-:$ Temperature. 


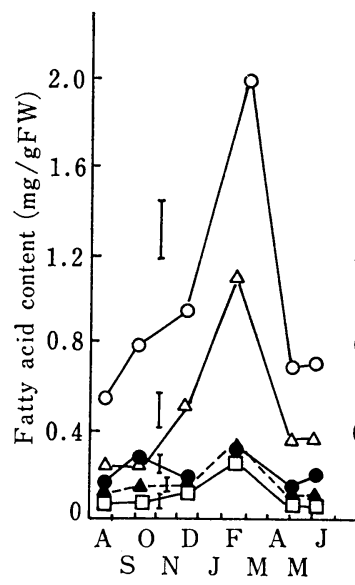

Neutral lipid

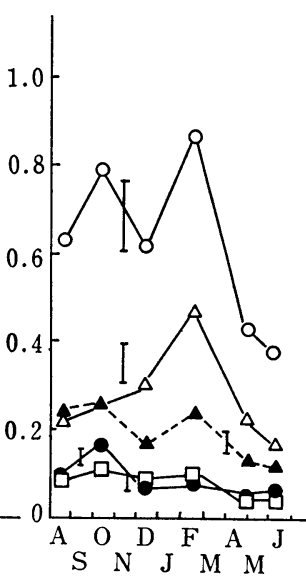

Month

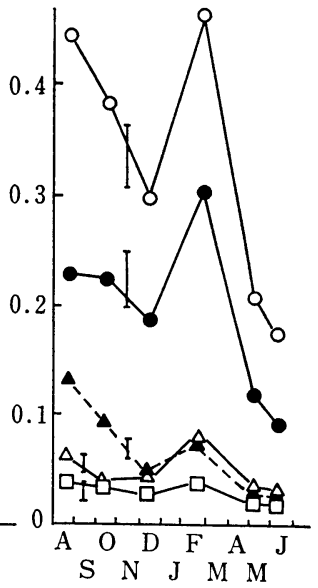

Glycolipid

Fig. 2. Changes in neutral, phospho- and glycolipid fatty acid content in the flavedo tissues during fruit development in 1985-1986. Vertical bars indicate L. S.D. $(5 \%)$

$\bigcirc-\bigcirc:$ Total, - $: 18: 3, \triangle-\triangle: 18: 2, \square-\square: 18: 1, \boldsymbol{\Delta}-\boldsymbol{\Delta}: 16: 0+18: 0$.

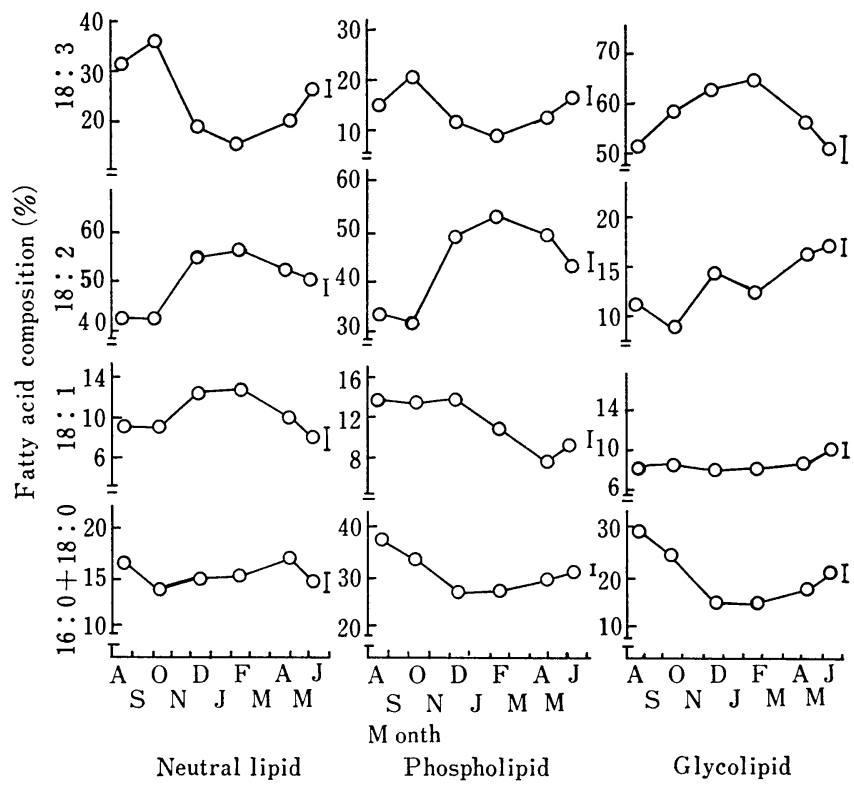

Fig. 3. Changes in neutral, phospho- and glycolipid fatty acid composition in the flavedo tissues during fruit development in 1985-1986. Vertical bars indicate L. S. D. $(5 \%)$

February, then markedly decreased in AprilJune. The phospholipid total fatty acid content showed two peaks, one in October and another in February; the first peak was due to the increase in both $16: 0+18: 0$ and 18 :
3 , and the second peak was due largely to the increase in $18: 2$. After the second peak, they sharply decreased toward AprilJune. The glycolipid total fatty acid content decreased (about 30\%) from August to 

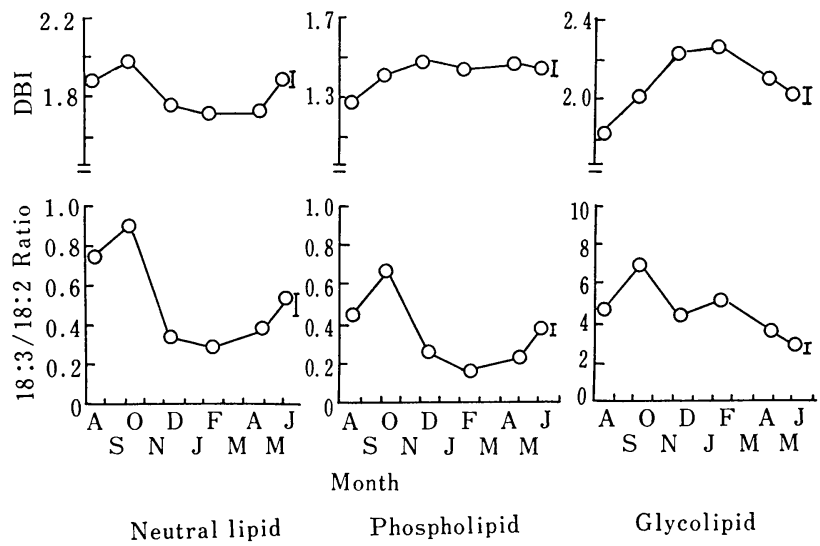

Fig. 4. Changes in $18: 3 / 18: 2$ ratio and double bond index in neutral, phosphoand glycolipids in the flavedo tissues during fruit development in 1985-1986. Vertical bars indicate L. S. D. (5\%)
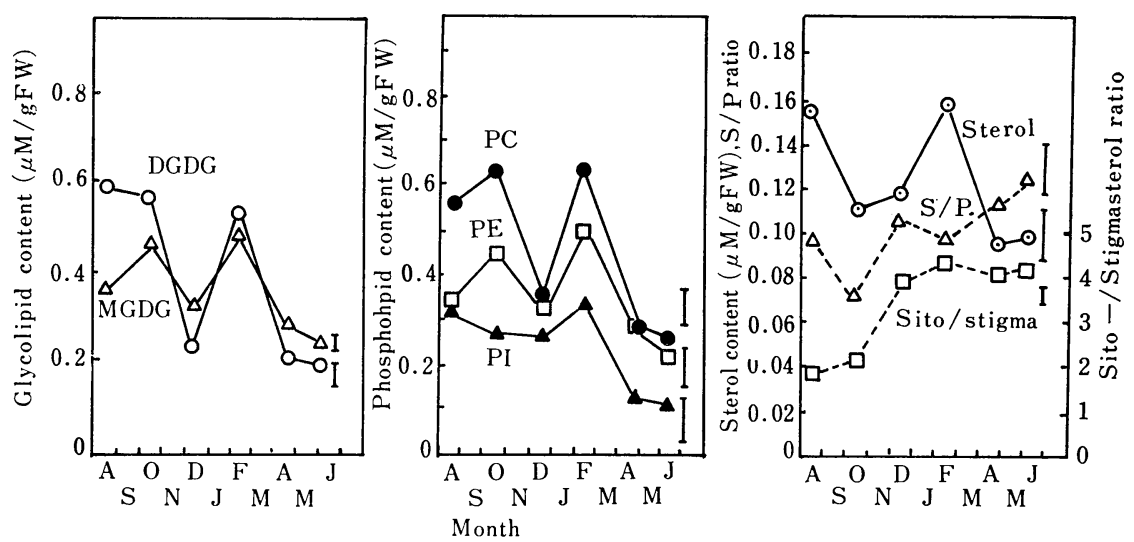

Fig. 5. Changes in major glycolipid, phospholipid and free sterol content in the flavedo tissues during fruit development. Vertical bars indicate L. S. D. (5\%) $\bigcirc-\bigcirc:$ DGDG, $\triangle-\triangle: M G D G$,

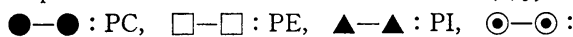

Total free sterol ( $\beta$-Sito-, stigma- and campesterol), $\triangle \cdots \triangle:$ Sterol/phospholipid (S/P) ratio, $\square \cdots \square: \beta$-Sitosterol/stigmasterol ratio.

December, due largely to the decrease in 16 : $0+18: 0$ and $18: 3$, then increased (about $30 \%$ ) in February, due largely to the increase in $18: 3$, followed by a sharp drop. In April-June, they decreased to less than half of the level of August-October.

In neutral and phospholipids, the $18: 2$ proportion increased and the $18: 3$ proportion decreased from October to February, and thereafter the trends were reversed (Fig. 3). Thus, the $18: 3 / 18: 2$ ratio became lowest in February (Fig. 4). In contrast, the $18: 3$ proportion in glycolipids was higher in February than before and after that, although the $18: 3 / 18: 2$ proportion tended to decrease from October to early June. DBI of phospho- and glycolipid fatty acids became slightly higher in mid-winter, while that of neutral lipids became slightly lower (Fig. 4).

Polar lipids and sterols The major components of phospholipids were PC, PE and phosphatidylinositol (PI) ; phosphatidylglycerol was negligible. Those of glycolipids were MGDG and DGDG. The changing patterns of major phospholipid $\mathrm{PC}$ and $\mathrm{PE}$ con- 
tent, and major glycolipid DGDG and MGDG content (Fig. 5) resembled essentially those of the phospholipid and glycolipid total fatty acid content, respectively. They decreased from October to December, and increased to a sharp peak in February, followed by a rapid drop. Major glycolipid content decreased more dramatically than major phospholipid content in May-June. The seasonal variations of DGDG content were paralleled by, but were greater than those of MGDG. The $\mathrm{PC} / \mathrm{PE}$ ratio steadily decreased from 1.7 in August to 1.1 in December, and thereafter remained unchanged.

The principal free sterols were $\beta$-sitosterol, followed by stigmasterol, then campesterol (Fig. 5). The free sterol contents decreased considerably from August to October, then increased considerably toward February, followed by a rapid drop. The sitosterol/stigmasterol ratio was about 2 in August-October, but doubled in December and thereafter. The sterol/phospholipid ratio slightly decreased from August to October, then slightly increased in December, and changed little thereafter.

\section{Discussion}

The total fatty acid content of neutral, phospho- and glycolipids showed a sharp peak in mid-winter when the air temperature reached a minimum. This peak was due largely to an increase in $18: 2$ in neutral and phospholipids, and $18: 3$ in glycolipids.

During temperature acclimation the accumulation of polyunsaturated fatty acids has been observed in a wide variety of plants. In the leaves of citrus seedlings, a specific increase in $18: 2$ of major neutral and phospholipids was reported upon hardening(23). In apple leaves, an increased 18:3 level was found associated with an increase in cold resistance (13). Rapid increases in polyunsaturated fatty acids in the flavedo tissues of Naruto fruits in mid-winter may result from cold acclimation, and may be responsible for increasing membrane fluidity(30).

The chloroplast is the most sensitive organelle in leaf tissues $(14,22)$. In this respect, the most noteworthy feature was that the
$18: 3$ proportion and the $18: 3 / 18: 2$ ratio in glycolipids, which are mainly contained in chloroplasts, were maintained high during mid-winter, while the reverse was true in neutral and phospholipids. Since $18: 3$ may be formed by stepwise desaturation of $18: 1$ and $18: 2(10)$, it seems that a rapid accumulation of $18: 3$ in glycolipids occurs at the expense of $18: 2$. On the other hand, the accumulation of $18: 2$ in neutral and phospholipids may be due partly to a decreased desaturation of $18: 2$ to $18: 3$.

Membrane fluidity during temperature acclimation can be regulated by a preferential accumulation of lipid species characterized by polyunsaturated fatty acids without significant changes in fatty acid unsaturation within them $(11,15)$. Our data show that increases in major glycolipid MGDG and DGDG, and major phospholipid PC and PE during mid-winter were paralleled by those of total (assessed by fatty acids) glyco- and phospholipids.

Free sterols are structual components of the membranes and are thought to result in a decrease in membrane fluidity $(4,8)$. Yoshida(30) reported that the sterol/phospholipid ratio of mulberry bark cells decreased during cold acclimation. In the present study, although the sterol contents considerably increased in mid-winter, the sterol/phospholipid ratio was relatively constant during winter. Similar results were obtained for winter wheat(29).

Total (assessed by fatty acids) and major phospho- and glycolipid content markedly decreased at the later stage of the maturation period (April-June) as compared with the growing period (August-October). The reduction of glycolipids was larger than that of phospholipids. The $\mathrm{PC} / \mathrm{PE}$ ratio was also lower in April-June than in the growing period. A higher $\mathrm{PC} / \mathrm{PE}$ ratio is known to. increase membrane fluidity(19).

In the green tissues, a decrease in the 18 : 3 composition was associated with degreening (senescing) (21), and the reverse trend was observed upon regreening(28). In the present study, in neutral and phospho-lipids, the $18: 3$ composition and $18: 3 / 18: 2$ ratio 
decreased until February, and increased toward April-June when the rind regreened. Almost identical results were obtained in a 1984-1985 study(5). These changes could reflect aging of the rind, since the $18: 3 \mathrm{com}$ position in all lipid fractions in the rind of stored Naruto fruit decreased with its aging and increased with a decrease in the storage temperature(6). On the other hand, changes in the $18: 3$ composition in glycolipid could be related to changes in temperature rather than to aging of the rind.

The increase in the sterol/phospholipid ratio is known to be associated with aging $(2,16)$. Although the sterol/phospholipid ratio slightly increased at the early stage of the maturation period, little change was observed therafter. Grunwald(9) reported that the level of stigmasterol in tobacco leaves increased with their maturity. In contrast to his report, stigmasterol content in the flavedo tissues was higher and thus the sitosterol/stigmasterol ratio was lower during the growing period than during the maturation period. The evidence that stigmasterol is more effective than sitosterol to overcome the inhibition of cell division by Tetcylacis, a growth retardant, (7) suggests the possible involvement of stigamasterol in cell division.

\section{Literature cited}

1. BARlett, G. R. 1959. Phosphorus assay in column chromatography. J. Biol. Chem. 234 : 466-468.

2. Borochov, A., A. H. HAlevy and M. ShinitzKy. 1982. Senescence and the fluidity of rose petal membranes. Plant Physiol. 62 : 296299.

3. CogGins, Jr., C.W. and H. Z. Hield. 1968. Plant growth regulators. Reuther, W., L.D. Bachelor and H. J. Webber (ed.) The Citrus Industry II. 371-389. Univ. of California.

4. FORD, R. C. and J. BARBER. 1983. Incorporation of sterol into chloroplast thylakoid membranes and its effect on fluidity and function. Planta 158: 35-41.

5. FUH, B. S. and T. ICHII. Effects of aging and temperature on fatty acid composition of the flavedo tissue of Naruto (Citrus medioglobosa). J. Japan. Soc. Hort. Sci. $56: 344-351$.

6. FUH, B. S., T. ICHII, Y. KAWAI and T. NAKANISHI. Changes of lipid composition in the flavedo tissue of Naruto (Citrus medioglobosa) during storage, and effects of growth regulators and storage temperature. J. Japan. Soc. Hort. Sci. (in press)

7. Grossmann, K., E. W. Weiler and J. Jung. 1985. Effects of different sterols on inhibition of cell culture growth caused by the growth retardant tetcyclacis. Planta 164 : $370-375$.

8. GRunwald, C. 1971. Effect of free sterols, sterrl ester, and steryl glycoside on membrane permeability. Plant Physiol. 48:653655.

9. GRUnWald, C. 1975. Phytosterols in tobacco leaves at various stages of physiological maturity. Phytochemistry $14: 79-82$.

10. HARWOOD, J. L. 1975. Fatty acid biosynthesis. Galliard, T. and E.I. Mercer (ed.) Recent Advance in the Chemistry and Biochemistry of Plant Lipids p. 43-88. Academic press.

11. Horvath, I., L. Vigh, PH. R., Van Hasselt, J. Woltjes and P. J.C. Kuiper. 1983. Lipid composition in leaves of cucumber genotype affected by different temperature regimes and grafting. Physiol. Plant. $57: 532-536$.

12. ICHII. T. and K. HAMADA. 1978. Studies of 'rind yellow spot', a physiological disorder of Naruto (Citrus medioglobosa Hort. ex Tanaka). J. Japan. Soc. Hort. Sci. 46 : $442-448$.

13. Ketchie, D. O. and P. J. C. KUiper. 1979. Fatty acid levels in apple leaves of different age as affected by temperature. Physiol. Plant. 46 : 93-96.

14. Kimball, S. L. and F. B. Salisbury. 1973. Ultrastructural changes of plant exposed to low temperatures. Amer. J. Bot. $60: 1028-$ 1033.

15. KUIPER, P. J. C. 1970. Lipids in alfalfa leaves in relation to cold hardiness. Plant Physiol. 45:681-686.

16. LeEs, G. L. and J. E. THOMPSON. 1980. Lipid composition and molecular organization in plasma membrane-enriched fractions from senescing cotyledons. Physiol. Plant. 49: $215-221$.

17. MCKERSIE, B. D., J. R. LEPOCK, J. E. KRUUV and J. E. THOMPSON. 1978. The effects of cotyledon senescence on the composition and physical properties of membrane lipid. Biochem. Biophys. Acta $508: 197-212$.

18. Metcalfe, L. D. and A. A. Schmitz. 1961. The rapid preparation of fatty acid esters for gas chromatographic analysis. Anal. Chem. 
$33: 363-364$.

19. Michaelson, D. M., A. F. Horwitz and M.P. KLEIN. 1974. Head grop modulation of membrane fluidity in sonicated phospholipid dispersions. Biochemistry $13: 2605-2611$.

20. NAGy, S., H. E. Norbdy and J. M. Smoot. 1975. Lipid composition of commercially canned single-strength orange juice. J. Am. Oil Chem. Soc. $52: 121-123$.

21. NeWman, D. W., B. W. P owell and K. Byrd. 1973. Lipid transformations in greening and senescing leaf tissue. Plant Physiol. 51: 229-233.

22. NOBEL, P.S. 1973. Temperature dependence of the permeability of chloroplasts from chilling-sensitive and chilling-resistant plants. Planta 115 : 369-372.

23. NORDBy, H. E. and G. YELENOSKY. 1982. Relationships of leaf fatty acids to cold hardening of citrus seedings. Plant Physiol. 70 : $132-135$.

24. O’ Neill, S. D., D. A. Pristley and B. F. ChABOT. 1981. Temperature and aging effects on leaf membranes of a cold hardy perennial, Fragaria virginiana. Plant Physiol. 68: 1409-1415.
25. PAUlS, K. P. and J.E. THOMPSON. 1981. Effects of in vitro treatmemt with ozone on the physical and chemical properties of membranes. Physiol. Plant. 53 : 255-262.

26. QUinN, P. J. and W. P. WILliams. 1978. Plant lipids and their role in membrane function. Prog. Biophys. Molec. Biol. 34 : 109-173.

27. Roughan, P. G. and R. D. BAtT. 1968. Quantative analysis of sulfolipid (sulfoquinovosyl diglyceride) and galactolipids (monogalactosyl and digalactosyl diglycerides) in plant tissues. Anal. Biochem. $22: 74-88$.

28. Wetterau, J. R., D. W. Newman and J. G. JAWORSKI. 1978. Quantitative changes of fatty acids in soybean cotyledons during senescence and regreening. Phytochemistry $17: 1265$ 1268.

29. Willemot, C. 1980. Sterols in hardening winter wheat. Phytochemistry 19:10711073.

30. YoshidA, S. 1984. Chemical and biophysical changes in the plasma membrane during cold acclimation of mulberry bark cells (Morus bombycis Koidz. cv. Goroji). Plant Physiol. $76: 257-265$.

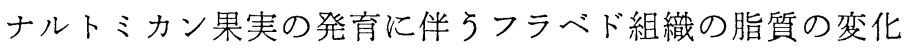

\author{
傳 炳 山 \\ 神戸大学自然科学研究科 \\ 一井隆夫・中西テッ・河合義隆 \\ 神戸大学農学部 657 神戸市灘区六甲台町
}

\begin{abstract}
摘 要
本研究は晚生カンキッの一つであるナルトミカン果皮 フラベド組織の脂質の季節的変化を調べた.

果実重は11月上旬まで增加し，その後の变化は少なか った。着色は10月下旬頃から始まり，2月に最も紅色が 濃くなったが，以後回青の傾向を示した.

リン及び糖脂質の脂肪酸総量, とくに糖脂質の総量は 果皮の成熟に伴って, 著しく減少した。ただし, 䇴冬期 ( 2 月）にはとくに高度不飽和脂肪酸の著しい増加がみ られた。中性, リン脂質は主にリノール酸 $(18: 2)$, 糖 脂質はりノレイン酸 $(18: 3)$ の增加によるものであっ た.

主要リン脂質である $\mathrm{PC}, \mathrm{PE}$ 及び主要糖脂質である DGDG, MGDG 量はそれぞれりン及び糖脂質の総量 (脂 肪酸総量）と平行して変化した. DGDGの季節的变化 は MGDG より大きかった。

$\mathrm{PC} / \mathrm{PE}$ の比は 8 月から 12 月までに漸減し, その後一 定であった。遊離ステロールの量は 8 月から10月にやや 減少し, 簃冬期にピークがみられた。しかし, ステロー ル/リン脂質の比は冬期中, 汪とんど変化がみられなか った. 成熟期（12月から6月）のシトステロール/スチ グマステロールの比は生育期（8月から10月）に比べ. 2 倍以上に達した。
\end{abstract}

